\title{
Management of the development of human capital of the airline using personnel logistics tools
}

\author{
Sergey Smerichevskyi ${ }^{1 *}$, Yuri Kolbushkin ${ }^{2}$, Anatoly Mikhnenko ${ }^{3}$, and Olga Polous ${ }^{4}$ \\ ${ }^{1}$ National Aviation University, Department of Marketing, 1, Kosmonavta Komarova ave., Kyiv, 03058 \\ Ukraine \\ ${ }^{2}$ Department of economic planning and budget calculations NJSC "Naftogaz of Ukraine", 6, B. \\ Khmeljnyckogho str., Kyiv, 01601 Ukraine \\ ${ }^{3}$ National Aviation University, Department of management and administration, 1, Kosmonavta \\ Komarova ave., Kyiv, 03058 Ukraine \\ ${ }^{4}$ National Aviation University, Department of Air Transport Economics, 1, Kosmonavta Komarova \\ ave., Kyiv, 03058 Ukraine
}

\begin{abstract}
The article deals with the main approaches to the definition of "personnel logistics". The study of approaches to the definition of "personnel logistics" can reveal the lack of a unified approach to its understanding. The expediency of using personnel logistics tools in managing the development of human capital of the enterprise is established. The human capital of the enterprise is in constant motion, varying in size and structure, it can be said that to create a system for managing the development of human assets of the enterprise appropriate to apply a logistic approach. The sectoral features of airline personnel management are presented. The system of management of development of human capital of the airline with the use of personnel logistics tools is offered. The process approach to the system allows constructing an adaptive personnel management system with feedback on the basis of the logistic concept, since these processes act as objects of management of this scientific direction. The technologies of management of development of human capital of the airline with the use of personnel logistics tools are systematized.
\end{abstract}

\section{Introduction}

The quick development of the transport sector in Ukraine requires the introduction of innovative technological, scientific and managerial achievements in the practice of domestic transport companies. For airlines in the context of operating in a changing global aviation space, entering the markets of other countries and the development of international business as one of the most important areas of activity are of particular importance. A key role in this process is played by the management of the development of human capital of the airline, which includes management of personal, monetary and occupational careers of the personnel.

\footnotetext{
* Corresponding author: os_f_smerichevsky@ukr.net
} 
The combination of these types of management into a single effective system is impossible without the use of the latest personnel logistics tools.

The issue of the adaptation of personnel logistics tools to the needs of management of the development of human capital of airlines is not sufficiently investigated in modern conditions. Conducting research in this area will further develop the theories of human capital management and deepen understanding of the personnel logistics tools inherent in the airline itself.

The purpose of the article is to develop a management system for the development of human capital of the airline using personnel logistics tools.

\section{Theory of the matter}

The management of the human capital development of enterprises and individual workers was carried out at various stages within the concepts and schools of human resources management. Earlier concepts in this area of study are classical concepts (F. Taylor, L. Gilbert, M. Emerson, O. Gastev, P. Kerzhentsev, M. Vitko, F. Dunaevsky) [12], the concept of administrative management (A. Fayol, M. Follet, C. Barnard) [13], bureaucratic concept (M. Weber) [22], the concept of "human relations" (E. Mayo, F. Rotisserberger, P. Layckert) [20], the concept of human resources and the school of behavioral sciences (V. Scott, M. Folette, A. Maslow, D. McGregor, W. Ouchi) [19], the concept of a situational approach (J. Woodworth, V. Vroom, M. Stevenson, F. Fiedler, P. Gersy and C. Blanchard, R. Blake and D. Mouton), the concept of a systematic approach (P. Drucker, R. Lickert, T. Peters, R. Waterman, I. Ansoff) [17] and the concept of institutional approach (D. North) [9]. Modern concepts in this area include the theory of human capital (M. Becker, J. Minster, T. Schultz), the theory of strategic human resources management (S. Fombrun, M. Bir, P. Boksall, D. Gest, D. Story, D. Parcel, K. Legge, D. Ulrich, and others) and competency-oriented approach (J. Hotkinson, P. Sperrou, A. Farnem, M. Armstrong, etc.) [1].

It should be noted that the issue of personnel logistics at this stage remains not fully investigated. A number of scholars $[4,6,7,8,11,14,21]$ define personnel logistics as one of the directions of logistics or as a term. The issue of staffing of airline companies is covered in a number of works $[2,3,5]$, which consider its interconnection with other resource components of the companies.

\section{Discussion of results}

In domestic and foreign scientific literature, most logistics professionals consider logistics, above all, as the management of material, informational and financial resources. Only some of them include into the objects of logistic control flows of resources of a different kind: energy and human. But they see these flows through the prism of creating value during the production process, while, for example, human flows are directed not only to production processes. They function separately from the latter. So, in any organization, there are personnel flows, and during their movement they also create value, but the cost including a different kind, namely, capitalized human cost. In addition, under special conditions of functioning contributing to the development of human potential and increasing the motivation of personnel, there is a synergistic effect during the movement of human flow within the organization, which does not occur as a result of the movement of resource flows of another kind. In other words, the input staffing flow in the organization, as it were, increases with its potential under the influence of the enterprise management system as a whole and the system of personnel management in particular. 
Today, the issue of the introduction of personnel logistics in the management system of human capital development of the enterprise is not paid enough attention. Thus, the study of approaches to the definition of "personnel logistics" can reveal the lack of a unified approach to its understanding.

Formation and development of human capital of an enterprise occurs during the organizational transfer of employees, which can be compared with the migration process at the macroeconomic level. It is precisely in the process of personnel movement at the enterprise that the exchange of information and abilities is intensified, the change of motivational units, which, based on the definition of human capital, is directly related to the process of its development.

Thus, the process of career management of employees today is transformed into a process of managing the development of human capital of the enterprise, since the human resources flow is a stream of human assets of the enterprise. Since the human capital of the enterprise is in constant motion, varying in size and structure, it can be said that to create a system for managing the development of human assets of the enterprise appropriate to apply a logistic approach.

Today, the aviation sector is extremely important for the stable development of our state in the conditions of intensification of the processes of integration and globalization. The volumes of passenger transportation by domestic airlines annually demonstrate steady growth, which entails the creation of new jobs, the use of the latest technologies of service provision and business, which, in turn, positively reflects on the Ukrainian economy. According to the results of 2018, the five largest passenger airlines carried 11620.6 thousand people, which is 20.2 percent more than in 2017, and accounts for almost 93 percent of the total passenger transportation volume of Ukrainian airlines (Fig. 1) [10].

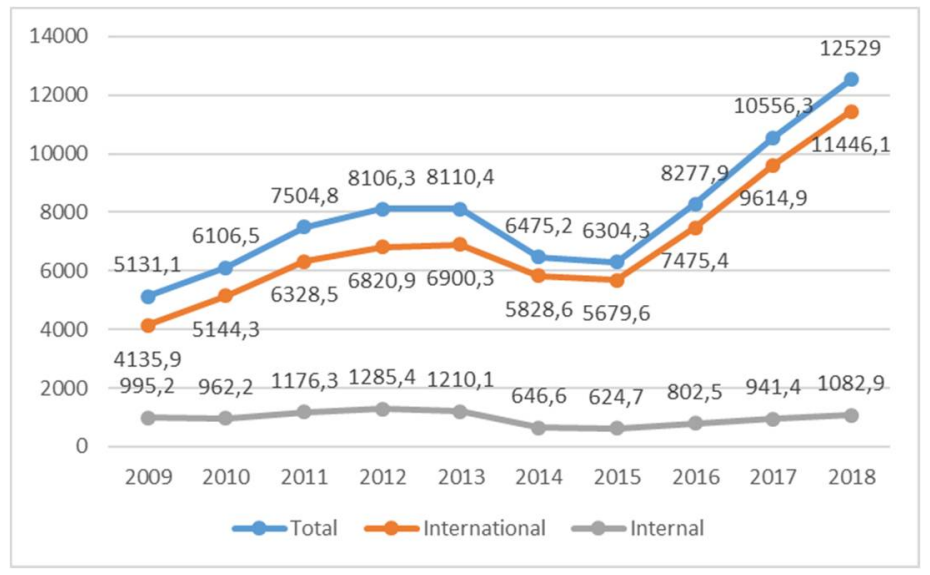

Fig. 1. Dynamics of volumes of transportation of passengers by air transport of Ukraine, ths. [10]

Such dynamic development requires airlines to quickly and qualitatively adaptation to changes in the environment and the needs of the domestic and foreign markets for providing aviation services, which is impossible without the development of human capital in accordance with the strategic objectives of the airlines and the aviation sector as a whole. These goals require the development of a new, innovative approach to managing the development of human capital of the airline using existing personnel tools and gradually transforming them in accordance with international standards for the provision of aviation services. 
The main criteria for the formation of human capital and its further development, put forward by international aviation companies include [18]:

- age - depending on the requirements of the airline. The maximum age must be between 25 and 35 years old;

- $\quad$ level of education - university or college education;

- $\quad$ knowledge of English, which is a key prerequisite of hiring by an airline;

- $\quad$ health information - applicants must undergo a preliminary medical examination and provide a health certificate;

- $\quad$ work experience - although this is not a specific requirement, preference is given to candidates who have already worked in this industry.

Most airlines abroad, if needed, turn to specialized companies to hire and recruit personnel. Aeropeople and Aerotek are the leading companies whose expertise is the strength and staffing of airline personnel in the UK, the United States and Europe as a whole. Another area of their work is cooperation with leading organizations that help in recruiting employees at all levels, as well as offering candidates for positions according to the specifics of the work, the location of the company or the industry itself.

Aeropeople and Aerotek are members of REC, the Recruitment \& Employment Confederation, known for its strict code of conduct, which ensures high quality work practices. Aeropeople and Aerotek are fully accredited to ISO 9002 (international quality system standard) $[15,16]$.

An important advantage of Aeropeople and Aerotek is the availability of an extensive network of more than 150 offices worldwide, and specialized units that provide aviation employment services, help airlines hire skilled workers, including administrative staff.

However, the main staffing and its further development are still engaged by the airlines themselves. We are invited to build an adaptive system for managing the human capital development of the airline based on personnel logistics. It involves the allocation of a single function of management human flows, the integration of management of human capital development into a single system of personnel management of the airline (Fig. 2).

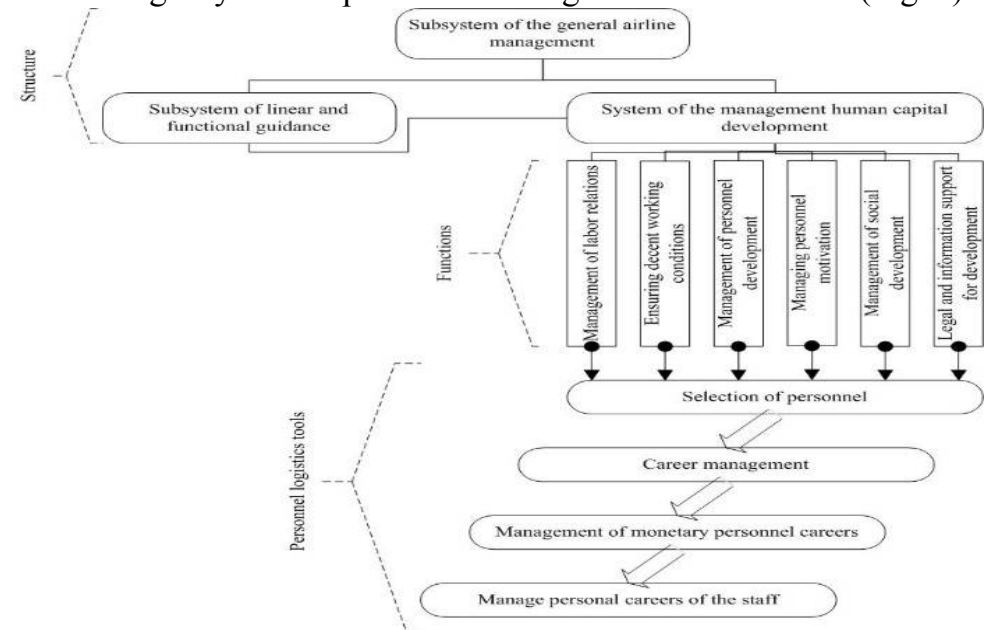

Fig. 2. Human capital development management system with the use of personnel logistics tools

Thus, HR processes can be defined as a separate set of actions aimed at transforming the human capital of the airline. It should be noted that they take place within any organization and, accordingly, any human resources management system, which is reflected in the ISO 9000 standard, where a number of human resources processes are presented as an organization's auxiliary business processes. 
The functions of the management system for the development of human capital of the airline belong to the responsibilities that form the system of structural elements, namely, the personnel management units and managers of the units of general and linear control. In connection with this, the main functions of this system are: hiring, accounting, legal support, marketing of personnel, etc., presented on Fig. 2.

Personnel development, staffing and monetary transfer of personnel, and selection of personnel were considered as the main personnel processes. The presented system reflects the composition of the management subsystems for developing the human capital of the airline on the basis of a functional and process approach. From the scheme it is clear that a number of functions in the management of personnel are carried out by heads of various units and management of the entire company. In this case, the personnel management processes are mainly the responsibility of the personnel management systems, not of individual leaders. Each the departments and/or employee of the latter concentrate their efforts on a certain function of personnel management, which results in the loss of integrity of managerial influence on staff. At the same time, dynamism and constant change in the personnel assets of the airline allow building a system for managing human capital development on the principles of a process approach, when all functions of personnel management are integrated into unified processes of career management of personnel and selection of employees.

The process approach to the system allows constructing an adaptive personnel management system with feedback on the basis of the logistic concept, since these processes act as objects of management of this scientific direction. In general, the difference between the logistic approach to human resources management and human capital from the traditional one is to allocate a single management function in the beginning of isolated human flows and their management processes, the integration of individual units of the personnel management service and functional units of the airline into a single system of personnel management.

Thus, the use of personnel logistics tools enables to create an objective set of technologies for managing the development of human capital of the airline (Fig. 3), aimed at increasing and improving the utilization of human capital of the company, achieving its goals and staffing.

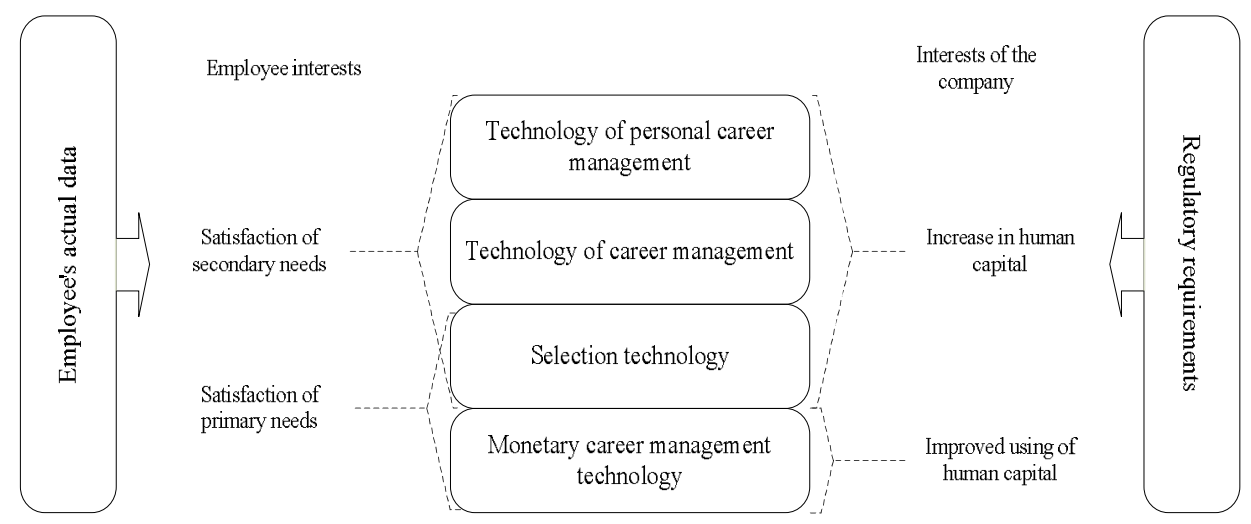

Fig. 3. Technologies for managing the human capital development of the airline using personnel logistics tools

This allows assessing the efficiency of spending on human resources both from the standpoint of the company and employees separately, and from the position of two entities taken together. Fig. 4 shows technologies in a hierarchical sequence, reflecting the orientation of each technology to meet the specific needs of staff. Thus, the technology of monetary career management is aimed at satisfaction of the basic needs of employees, and the 
technology of career and personal career management are aimed at meeting secondary needs. The location of selection technology in this hierarchical sequence is determined by the fact that during the selection, employees tend to take the position of career space which will allow them to improve their financial position, improve their status, and develop. In other words, this technology allows meeting both the primary and secondary needs.

\section{Conclusion}

Consequently, from the point of view of managing the development of human capital, the organizational movement of human assets of the company can be reduced to three main vectors: career, monetary and personal. The personal career vector is directly linked to the increase in the value of human assets due to changes in staff abilities. Moving along the vector of an official career means creating a favourable opportunity for the growth of human capital, as well as, in conjunction with the movement on the vector of a monetary career, increases the loyalty of employees by increasing their interest. Increasing motivation, in turn, leads to an increase in human capital. Consequently, during the career movement of human assets there is a change in the size of human capital, its development.

So, using the aforementioned technology complex, the airline will be able to increase the size of human capital (with the application of selection technologies, management of the public and personal careers) and improve its use (in the case of applying monetary management technology). Thus, in the case of the practical implementation of this set of technologies, it will be possible to meet the interests of both parties - the employee and his employer.

Subsequent research will be aimed at studying the management system of human capital development of a specific domestic airline with the development of solutions to existing problems with the use of personnel logistics tools.

\section{References}

1. Armstrong M. Strategicheskoe upravlenie chelovecheskimi resursami [Strategic human resource management]. Moscow: INFRA-M. (in Russian) (2002)

2. Vysotskaya M.P. Formirovanie kadrovoy politiki aviapredpriyatiy Ukrainy [Formation of personnel policy of Ukrainian aviation enterprises]. Kyiv: NAU. (in Russian) (2005)

3. Grabs-Uest L. Sotrudniki na vsyu zhizn': Uroki loyal'nosti ot Southwest Airlines [Employees for all life: Southwest Airlines loyalty lessons]. Moscow: Mann, Ivanov i Ferber (in Russian) (2008)

4. Kormin N.G. Bulletin of Chelyabinsk State University, 7(108), 138-141 (2008)

5. Lashhenko O.Ju. Upravlinnja kadrovym zabezpechennjam ekonomichnoji bezpeky aviakompanij [Management of human resources provision of economic safety of airlines] (PhD Thesis), Kyiv: National aviation university (2010)

6. Leontjjeva I.O. Kadrova loghistyka v systemi upravlinnja vodnotransportnym pidpryjemstvom [Personnel logistics in the management of the water transport enterprise]. Scientific herald of Kherson State University. Economic sciences, 20, 1, 111-114 (2016)

7. Meljnykova K.V. Scientific herald of Kherson State University. Economic sciences, 17, 3, 58-60 (2016)

8. Mishyna S.V., Mishyn O.Ju. Economics and society, 12, $492-499$ (2017)

9. Nort D. Instituty, institutsional'nye izmeneniya i funktsionirovanie ekonomiki [Institutions, institutional changes and the functioning of the economy]. Moscow: Fond ekonomich. knigi «Nachala». (in Russian) (1997) 
10. Ministry of infrastructure of Ukraine. Pidsumky dijaljnosti aviacijnoji ghaluzi Ukrajiny za 2018 rik [The results of the aviation industry in Ukraine for 2018]. Available at: https://mtu.gov.ua/content/statistichni-dani-v-galuzi-aviatransportu.html?PrintVersion (accessed 05.05.2019) (2018)

11. Serbin V.D. Osnovy logistiki [Basics of logistics]. Taganrog: TRTU. (in Russian) (2004)

12. Teylor F. Nauchnaya organizatsiya truda [Scientific organization of labor]. Moscow: NKPS Transpechat'. (in Russian) (1925)

13. Fayol' A. Obshchee i promyshlennoe upravlenie [General and industrial management]. Moscow: Kontrolling. (in Russian) (1992)

14. Chemekov V.P. Management technology, 12, 25-28 (2002)

15. Aeropeople. Official site. Available at: http://www.aeropeople.com/ (accessed 04.05.2019).

16. Aerotek. Official site. Available at: http://www.aerotek.com/ (accessed 04.05.2019).

17. Drucker P.F. Management: Tasks, Responsibilities, Practices. N.Y. Harper and Raw. 398 p. (1973)

18. International Civil Aviation Organization. Official site. Available at: https://www.icao.int/ (accessed 04.05.2019).

19. Maslow A.A. Theory of Human Motivation. Psychological Review, 50, 370-396 (1943)

20. Mayo E. The Human Problems of an Industrial Civization. Boston: Graduate School Administration, Harvard University. 318 p. (1946)

21. Velychko O., Velychko L. Journal of international studies, 10, 3, 206-219 (2017)

22. Weber M. The Theory of Social and Economic Organizations N.Y.: Free Press. 436 p. (1947) 